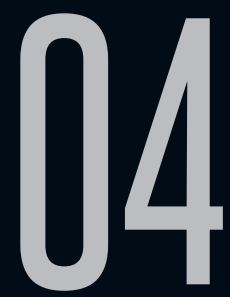

\title{
FIGURAÇÃO DE PERSONAGENS-TÍTULO NA CONTÍSTICA DE MURILO RUBIÃO ${ }^{1}$
}

\author{
Flavio García (UERJ) \\ Juliana Cavalcante do Amaral (UERJ)
}

Recebido em 12 set 2020. Flavio García é professor associado da UERJ; bolsista Aprovado em 01 nov 2020. PROCIÊNCIA (UERJ-FAPERJ); orienta iniciação científica, mestrado e doutorado e supervisiona pós-doutorado. É pós-Doutor pela UFRJ (2008), pela UFRGS (2012) e pela Universidade de Coimbra (2016), e pósDoutorando pela Universidade de Lisboa (2020-2022), com projetos de pesquisa sobre o insólito ficcional e/ou sobre a ficção de Mia Couto. Líder do grupo de pesquisa "Nós do Insólito: vertentes da ficção, da teoria e da crítica" junto ao Diretório de Grupos do CNPq; coordena o SePEL. UERJ (www.sepel.uer.br); é um dos editores do e-DDIF (www.insolitoficcional.uerj.br). Lattes: http://lattes.cnpq.br/4242057381476599.

E-mail: flavgarc@gmail.com

ORCID iD: https://orcid.org/0000-0003-0761-8092

Juliana Cavalcante do Amaral é Graduanda pela UERJ. Bolsista PIBIC/CNPq com projeto sobre Murilo Rubião.

Resumo: O presente trabalho, baseado essencialmente nos estudos narrativos, tem por objetivo inicial destacar, do conjunto de contos de Murilo Rubião,

1 Este ensaio é produto parcial do projeto de pesquisa de iniciação científica de mesmo título, desenvolvido com bolsa PIBIC-CNPq, sob a orientação de Flavio García, bolsista PROCIÊNCIA UERJ/FAPERJ, com o projeto de pesquisa Macroestrutura semionarrativa dos mundos possíveis do insólito ficcional. 
aqueles em cujo título se verifique a presença de personagens-título, para, a seguir, observar, nesses contos, possíveis procedimentos discursivo-textuais utilizados pelo autor na figuração dessas personagens. Palavras-chave: Estudos narrativos; Figuração de personagens; Personagens-título; Contística; Murilo Rubião.

Abstract: Based essentially on narrative studies, the present paper has the initial objective to highlight, from the set of Murilo Rubião's short stories, the stories in whose title the presence of title-characters is verified, in order to subsequently observe potential textual-discursive procedures used by the author in the figuration of these characters.

Keywords: Narrative studies; Figuration of characters; Title-characters; Short stories; Murilo Rubião.

Tendo em vista a amplitude e a complexidade dos processos de figuração de personagens², observa-se que Murilo Rubião se utilizou de variados procedimentos discursivo-textuais para compor as figuras ${ }^{3}$ que são anunciadas no título de muitos de seus contos. Dos trinta e três textos que compõem a obra publicada do autor, observamos que, em vinte e seis deles, haveria personagem-

2 Conforme Carlos Reis, "[a] figuração designa um processo ou um conjunto de processos discursivos e metaficcionais que individualizam figuras antropomórficas, localizadas em universos diegéticos específicos, com cujos integrantes aquelas figuras interagem, enquanto personagens" (REIS, 2018, p.165). Em sua perspectiva, "a figuração é dinâmica, gradual, complexa, significando isto três coisas: primeira, que normalmente ela não se esgota num lugar específico do texto; segunda, que ela se vai elaborando e completando ao longo da narrativa; terceira, que, por [...] sua natureza dinâmica, a figuração não se restringe a uma descrição de personagem, nem mesmo a uma caracterização, embora esta possa ser entendida como seu componente importante. Assim, a figuração deve ser encarada como um macrodispositivo mais amplo, englobante e consequente do que a caracterização." (REIS, 2018, p.166)

3 Segundo Reis "O termo figura designa, em geral, toda a entidade ficcional ou ficcionalizada que desempenha funções na composição e na comunicação instaurada pelo relato ou que vive acontecimentos nele narrados. A manifestação mais evidente da entidade designada como figura é a personagem [...]" (REIS, 2018, p.162). 
título, ou seja, aquela que já aparece, de certa maneira, a partir de algum processo composicional, anunciada no título da narrativa. Em grande parte dessas narrativas, Rubião evidenciou mais de um elemento figurativo na anunciação da personagem-título. Assim, considerando o argumento de Carlos Reis de que "chamase personagem, essa categoria sem a qual não há relato que se sustente" (2014, p.49-50, grifo do original), é importante destacar a relevância desse elemento da narrativa para a compreensão dos mundos possíveis armados pelo autor ${ }^{4}$.

Em "O pirotécnico Zacarias", foram empregados três diferentes processos composicionais de personagem, dos quais, dois deles são os mais comuns no conjunto da obra de Rubião: a nomeação da personagem e o destaque de algum aspecto predicativo que a caracterize ou modifique. Em primeiro lugar, observamos a referência ao nome e/ou ao sobrenome da personagem em questão. Tal processo mostra-se significativo, uma vez que dá identidade às figuras. Além disso, no caso de

4 O "[...] mundo possível é um construto abstrato, funcionando como modelo alternativo ao mundo real" (REIS, 2018, p.274) que, neste caso, corresponde ao "mundo ficcional[,] uma entidade 'povoada' por elementos com feição concreta (personagens, objetos, lugares, etc.) [...]" (REIS, 2018, p.274). Assim, como Reis observa, "[n]o universo de referências dos mundos ficcionais, inscrevem-se as personagens, os seus atributos e as suas esferas de ação" (REIS, 2018, p.275).

5 Os contos selecionados para este ensaio serão apresentados na ordem em que aparecem publicados na edição da Companhia das Letras, cuja entrada se verifica nas Referências deste trabalho. São eles: (1) "O pirotécnico Zacarias", (2) "O exmágico da Taberna Minhota", (3) "Bárbara", (4) "Ofélia, meu cachimbo e o mar", (5) "A flor de vidro", (6) "Os dragões", (7) "Teleco, o coelhinho", (8) "A Casa do Girassol Vermelho", (9) "Alfredo", (10) "Marina, a Intangível", (11) "Os três nomes de Godofredo", (12) "Memórias do contabilista Pedro Inácio", (13) "Bruma (a estrela vermelha)", (14) "D. José não era", (15) "A Lua", (16) "O homem do boné cinzento", (17) "Mariazinha", (18) "Elisa", (19) "A noiva da Casa Azul", (20) "O bom amigo Batista", (21) "Epidólia", (22) "Petúnia", (23) "Aglaia”, (24) "O convidado", (25) "Botão-de-Rosa" e (26) "Os comensais". 
Zacarias, pode-se conjecturar que a nomeação da personagem Ihe confere condição humana, o que é um aspecto importante se considerarmos o fato de que o pirotécnico relata que muitas pessoas acreditam que "o indivíduo a quem andam chamando Zacarias não passa de uma alma penada, envolvida por um pobre invólucro humano" (RUBIÃO, 2010, p.10).

No título desse conto, ainda se verifica um termo adjetivo, com valor de predicação, "pirotécnico", em alusão ao mister que a personagem exercia antes de morrer. Ademais, é importante ressaltar que Rubião deixa claro tratar-se de figura do gênero masculino ${ }^{6}$, o que também configura um processo composicional. Ele nos apresenta um homem que foi atropelado e morreu em decorrência do acidente, mas que continua vivendo, inclusive, "com mais agrado do que anteriormente" (RUBIÃO, 2010, p.10). Zacarias, no entanto, sente-se frustrado, uma vez que não consegue convencer seus conhecidos de que é a mesma pessoa de antes, "com a diferença de que aquele era vivo e este, um defunto" (RUBIÃO, 2010, p.14). É interessante observar que a personagem, que desempenha a função de narrador ${ }^{7}$, evidencia a impossibilidade 6 Admitindo-se "A Casa do Girassol Vermelho" no universo dos vinte e seis contos em que Rubião se vale da personagem-título para nomear a narrativa, uma metade deles apresenta personagem no gênero masculino - "O pirotécnico Zacarias", "O exmágico da Taberna Minhota", "Os dragões", "Teleco, o coelhinho", "Alfredo", "Os três nomes de Godofredo", "Memórias do contabilista Pedro Inácio", "D. José não era", "O homem do boné cinzento", "O bom amigo Batista", "O convidado", "Botão-de-Rosa" e "Os comensais" - e outra, no feminino - "Bárbara", "Ofélia, meu cachimbo e o mar", "A flor de vidro", "A Casa do Girassol Vermelho", "Marina, a Intangível", "Bruma (a estrela vermelha)", "A lua", "Mariazinha", "Elisa", "A noiva da Casa Azul”, "Epidólia", "Petúnia" e "Aglaia".

7 A função do narrador, na ampla maioria da obra de Rubião, é desempenhada por personagens, ou seja, por um dos elementos que se encontram presentes no nível da diegese - entendida como plano do "conjunto de elementos significativos que integram a história contada numa narrativa" (REIS, 2018, p.87) -, variando entre narrador autodiegético - "a entidade que relata as suas próprias experiências como personagem 
de esclarecer a questão, uma vez que todos parecem evitá-lo a qualquer custo, e ele é o único capaz de "dar informações certas sobre o assunto" (RUBIÃO, 2010, p.10).

Em "O ex-mágico da Taberna Minhota", encontramos alguns dos mesmos procedimentos textuais utilizados em "O pirotécnico Zacarias" para destacar aspectos da composição da personagemtítulo. Novamente, a figura em questão é do gênero masculino, entretanto, seu nome e/ou sobrenome não foi destacado, mas sua procedência sim, o que também configura um tipo de processo composicional. Afinal, não se trata de um ex-mágico qualquer, mas do "ex-mágico da Taberna Minhota". Além disso, observa-se que a expressão "da Taberna Minhota" tem valor adjetivo de predicação, modificando o substantivo "ex-mágico".

A personagem sentia-se atormentada por desconhecer sua origem, uma vez que foi "atirado à vida sem pais, infância ou juventude" (RUBIÃO, 2010, p.15) e pelo fato de não conseguir controlar sua magia. Após ser mandado embora da Taberna Minhota por oferecer alimentos que "extraía misteriosamente de dentro do paletó" (RUBIÃO, 2010, p.15), gratuitamente, aos clientes do estabelecimento, ele vai trabalhar em um circo. Contudo, apesar de fazer sucesso entre os espectadores dos espetáculos circenses, a angústia da personagem, proveniente da falta de controle sobre sua magia, só aumentava.

Desse modo, o então mágico decide tentar o suicídio. Sua magia, porém, sempre acaba impedindo-o de concretizar seu desejo. Depois de três tentativas fracassadas, resolve tornar-se 
funcionário público, visto que "ouvira de um homem triste que ser funcionário público era suicidar-se aos poucos" (RUBIÃO, 2010, p.17). Após um ano de trabalho, diante da perspectiva de ser demitido e, consequentemente, afastado da colega de trabalho por quem havia se apaixonado - tenta provar que, por trabalhar há dez anos em uma Secretaria de Estado, não poderia ser demitido. No entanto, constata que "confiara demais na faculdade de fazer mágicas e ela fora anulada pela burocracia" (RUBIÃO, 2010, p.18). Assim, o agora ex-mágico, antes atormentado pela falta de controle sobre sua magia, lamenta "não ter criado todo um mundo mágico" (RUBIÃO, 2010, p.18).

Em "Bárbara", enunciam-se dois aspectos da composição da figura no título do conto: o nome e o gênero. Esse título, mais conciso se comparado aos anteriores, faz sentido se considerarmos como a narrativa e todo o mundo possível armado por Rubião gira em torno da personagem que dá nome ao conto e de seus desejos. O narrador fala de sua relação com Bárbara, que conhece desde a infância. Ainda menina, ela tinha por hábito fazer-lhe pedidos exagerados, e ele sempre atendia sem pestanejar, apesar de, em certas ocasiões, relutar em "aquiescer às suas exigências" (RUBIÃO, 2010, p.19). Nesta história, o insólito ${ }^{8}$, uma das mais importantes

8 Neste sentido, "Io insólito es todo aquello que resulta extraordinario. Lo que se sale de lo común, lo inusual, lo fabuloso o lo inexplicable" (LÓPEZ-PELLISA; RUIZ GARZÓN, 2019, p.XI).

"Sob a denominação abrangente de insólito ficcional se podem abrigar o fantástico - seja o gênero, seja especialmente o modo -; o maravilhoso - clássico, medievo, moderno ou contemporâneo -; o estranho - aquele de Freud trata em seu ensaio 'Das Unheimliche' ou o que Todorov apresenta como contíguo ao fantástico -; o realismo maravilhoso, bem como suas muitas variantes, admitindo-se o realismo mágico, o realismo fantástico, o realismo animista; o absurdo - independentemente de entendido como o propôs Sartre, Camus ou qualquer outro -; os contos de fada em geral - ficando-Ihes de fora muito poucas narrativas -; uma grande maioria das 
marcas da literatura de Rubião, conforme Antonio Candido bem observou ${ }^{9}$, é introduzido pelo ganho de peso excessivo de Bárbara, que vai engordando à medida que seus desejos despropositados são concedidos. Mesmo após o nascimento de um filho, ela não muda de comportamento, o que frustra o marido, que, resignado, parece não encontrar sentido em contrariar a esposa. É interessante observar a inconstância de Bárbara, que se enfastia rapidamente após ter suas vontades atendidas e continua a fazer pedidos exagerados e descabidos, a ponto de levar sua família à falência.

Em "Ofélia, meu cachimbo e o mar", mais uma vez, temos no título o procedimento figurativo de destaque com o nome da personagem, deixando expresso o gênero. Neste texto, conhecemos o relato de um homem que nasceu longe do litoral, em um vilarejo em Minas Gerais, e que tem o desejo de se tornar marinheiro. Após a morte do pai, ele decide ir morar em uma cidade litorânea para realizar seu sonho. Entretanto, suas tentativas são frustradas depois que ele fratura um dos pés. Essa personagem, que cumpre a função de narrador, menciona que gosta de "conversar com Ofélia na varanda após o jantar, cachimbo entre os dentes e o oceano, enegrecido pela noite, estendendose à nossa frente" (RUBIÃO, 2010, p.27). Nessas ocasiões, conta à Ofélia as supostas aventuras marítimas de sua família. Mas sua interlocutora, por sua vez, parece se entediar com o assunto, pois prefere "histórias de caçadas" (RUBIÃO, 2010, p.27).

narrativas de mistério e policial; uma boa quantidade de textos da ficção científica; as produções que se alinham nos cenários da ficção distópica ou da ficção pósapocalíptica; o fantasy" (GARCÍA, 2019).

9 Antonio Candido afirma que "Murilo Rubião instaurou no Brasil a ficção do insólito absurdo" (CANDIDO, 1987, p.208). 
Ele se consola trazendo à memória, constantemente, lembranças de seu bisavô, que teria sido capitão de navio negreiro. Afinal, "o que poderia fazer um aleijado com a vocação de navegante, depois que lhe roubaram o mar?" (RUBIÃO, 2010, p.28). Nesse ponto da narrativa, percebe-se uma espécie de tensão entre o narrador e Ofélia, que parece insatisfeita com as histórias contadas pelo companheiro. No final do texto, podemos entender melhor o motivo da aparente incompreensão da mulher, pois fica claro que todas as aventuras contadas pelo narrador não passam de devaneios. É possível conjecturar a respeito da escolha do título do conto por Rubião. A personagem é figurada como um homem frustrado, que nunca conseguiu realizar seu sonho. Imaginar toda uma realidade na qual um de seus antepassados teria uma relação com o mar era uma forma de justificar seus anseios, que nunca puderam ser concretizados. Assim, ele ressignifica seu mundo, resumindo-o à Ofélia, ao seu cachimbo e ao mar.

Em "A flor de vidro"10, temos uma locução adjetiva ("de vidro"), modificando o núcleo substantivo, empregada no processo composicional da personagem-título, que corresponde a uma figura antropomorfizada ${ }^{11}$.

10 Nesta história, flor nomeia uma personagem, e tal aspecto merece atenção, uma vez que Rubião se vale de referências a diferentes tipos de flora em outros de seus textos, o que demarca uma reincidência dessa estratégia em sua obra.

11 "O conceito de personagem pode ser definido [...] como a representação de uma figura humana ou humanizada [, ou seja, antropomorfizada,] que, numa ação narrativa, contribui para o desenvolvimento da história e para a ilustração de sentidos projetados por essa história [...]" (REIS, 2018, p.388). Compor personagens a partir de um objeto ou um animal antropomorfizado é recorrente na obra de Rubião. Dos vinte e seis contos que apresentam personagem-título, sete são intitulados por um objeto ou um animal antropomorfizado: "A flor de vidro", "Os dragões", "Teleco, o coelhinho", "A Casa do Girassol Vermelho", "Alfredo", "A lua" e "Petúnia". 
No conto, somos apresentados a Eronides, um homem que não enxerga de um olho e que sofre de saudades de Marialice, aparentemente uma antiga namorada, e temos a flor como elemento de rememoração de uma ausência, conforme defendido por Polyana Pires Gomes $(2018)^{12}$. Logo no início da narrativa, Eronides é surpreendido pela chegada inesperada de sua amada, e os dois tentam retomar o relacionamento. $\mathrm{O}$ insólito não demora a aparecer neste texto, já que, na manhã seguinte, ao acordar, ele se dá conta de que voltou doze anos no tempo e, tomado por uma ânsia de mudar os rumos de um destino que parece ser inevitável, tenta fazer com que Marialice não vá embora. Assim, seguem uma rotina, com passeios frequentes pelo campo, em alguns dos quais, ele pensa ter "divisado a flor de vidro no alto de uma árvore" (RUBIÃO, 2010, p.32), e teme a partida da mulher. Esse temor se confirma no final da narrativa. Logo após o adeus de Marialice, "a presença da flor de vidro revelou-se imediatamente" (RUBIÃO, 2010, p.32). Constatamos, então, o papel da flor de vidro de simbolizar a partida e a ausência da amada de Eronides, como propôs Gomes (2018, p.88).

Em "Os dragões", a personagem-título corresponde a figuras de um animal mítico-mitológico antropomorfizadas. $\mathrm{O}$ insólito está evidente já no título da narrativa, uma vez que dragões não existem em nossa realidade referencial. Como postula Eveline Coelho Cardoso (2007, p.40), os títulos de Rubião quase sempre destacam seja o próprio elemento insólito, seja algo ou alguém a ele relacionado. A história é narrada por um professor, que conta

12 "Uma flor de vidro o [Eronides] ajuda a lembrar, diariamente, da amada ausente" (GOMES, 2018, p.88). 
como a chegada de dragões a sua cidade suscitou debates sobre o que, de fato, seriam tais criaturas e qual seria a sua origem. Um padre defende que os dragões recebam nomes, sejam batizados e alfabetizados. A personagem-narrador parece ser o único habitante do lugar que acha tal sugestão despropositada. Sua posição a respeito do assunto é interessante e merece atenção especial, pois Rubião optou por não destacar os nomes que os dragões receberam - Odorico e João - no título do conto. O narrador tenta convencer seus companheiros de que as criaturas são apenas dragões, ao mesmo tempo em que essas figuras passam a experimentar sentimentos e conflitos e a ter hábitos próprios do ser humano, o que reafirma a antropomorfização.

Os dragões começam a ter vícios. Cardoso (2007, p.42) chamou atenção para o fato de que a degradação moral dos dragões pode ser uma consequência do contato com seres humanos. Odorico, inclusive, passa a viver com uma mulher casada depois que ela deixa o marido. O professor não media esforços para que eles abandonassem a vida desregrada que levavam, mas não foi bem sucedido. Odorico morreu após levar um tiro, provavelmente dado pelo marido da amante. João, mesmo depois de viver com o professor e sua esposa, que passaram a considerá-lo um filho, foi vítima da presunção, resultante do crescente prestígio que começou a desfrutar na cidade, a "admiração de uns, os presentes e convites de outros, acendiam-Ihe a vaidade" (RUBIÃO, 2010, p.35). No desfecho, ele desaparece. Aparentemente, o motivo de sua fuga foi a trapezista de um circo que lhe ofereceu uma proposta de trabalho. Ela teria sido "especialmente destacada para seduzi-Io" (RUBIÃO, 2010, p.35). 
Em "Teleco, o coelhinho", repete-se a antropomorfização de um animal, com o destaque do nome da personagem - "Teleco" -, seguido do determinante de sua espécie animal - coelho -, no grau diminutivo, o que pode sugerir afetividade - "coelhinho" -. É interessante comparar os procedimentos discursivo-textuais de "Os dragões" com os de "Teleco, o coelhinho". Teleco é um animal descrito pelo narrador, uma personagem coprotagonista ${ }^{13}$ da história, como gentil, alguém que tinha o "simples desejo de agradar ao próximo" (RUBIÃO, 2010, p.37). No início da história, o narrador parece ignorar que Teleco tem alguns comportamentos dissimulados, como assustar certos vizinhos de quem não gostava. Em sua opinião, "assustava-os mais para nos divertir que por maldade" (RUBIÃO, 2010, p.37).

O percalço narrativo se anuncia quando Teleco, que podia metamorfosear-se em diferentes animais, transforma-se em um canguru e afirma ser um homem chamado Antônio Barbosa ${ }^{14}$. Notase, então, como o fato de o nome do coelhinho ter sido destacado no título é significativo. Enquanto Teleco é um coelho meigo e gentil, na opinião do narrador, ainda que exerça travessuras e brincadeiras dissimuladas, quando ele se autointitula Antônio - e não qualquer um deles, mas Antônio Barbosa -, o narrador passa a vê-lo de modo diferente, e os atritos entre eles se iniciam. A tensão aumenta ainda mais porque o narrador se descobre apaixonado por

13 O protagonista é a personagem principal da história, atribuindo-se-Ihe, em geral, valores positivos. Há narrativas em que se verificam mais de uma personagem central. É comum, nesses casos, que uma personagem tenha valores que se considerem negativos, sendo chamada de antagonista. No conto de Rubião, tanto Teleco, quanto o narrador, são personagens protagonistas, logo, coprotagonista da mesma história.

14 A metamorfose é um tema bastante comum à ficção fantástica, a que Rubião recorreu em muitos de seus contos, variando estratégias compositivas. 
Tereza, que tem uma relação romântica com Teleco. No clímax da história, por ciúmes de Tereza e porque a "figura tosca" (RUBIÃO, 2010, p.39) de Antônio o repugnava, ele os expulsa de sua casa, que coabitavam. No fim do conto, Teleco, e não mais Antônio, reaparece, entristecido, junto ao narrador, metamorfoseado em cachorro. Busca reatar os laços de afetividade. Essa estratégia utilizada por Rubião nos faz refletir sobre como a figuração das personagens é relevante para a compreensão da história e, mais especificamente, como o procedimento textual de nomear uma personagem é significativo para o seu processo composicional. No desfecho, Teleco, sem conseguir controlar suas transformações, deita-se no colo do narrador, adormecendo e vindo a morrer na forma de "uma criança encardida, sem dentes" (RUBIÃO, 2010, p.41). Esse final correlaciona-se, de certa maneira, com início da história. No primeiro encontro de Teleco com o narrador, o "coelhinho cinzento" Ihe pede um cigarro, e o narrador lhe manda embora, chamando-o de "moleque" (RUBIÃO, 2010, p.36).

Alguns fatores nos levaram a considerar a existência de personagem-título em "A Casa do Girassol Vermelho". Gomes (2018, p.87) chama atenção para o fato de as palavras "Girassol Vermelho", que integram a locução adjetiva, serem grafadas com iniciais maiúsculas, o que poderia significar a personificação do substantivo "Casa”, que modificam. Grafamos os substantivos próprios com iniciais maiúsculas, e Rubião, ao que nos parece, utilizou tal recurso para deixar claro que não se trata de uma "Casa" apenas. No início do conto, o narrador, que é uma personagem, diz que a Casa do Girassol Vermelho "respirava uma alegria desvairada" (RUBIÃO, 2010, p.62). Tal manifestação do narrador corrobora a 
visão de Gomes (2018, p.87) de que a Casa teria sido personificada, pois respirar é um atributo dos seres vivos, e gozar de alegria é um sentimento mais específico dos seres humanos.

A personagem-narrador relata a alegria com qual, junto a seus irmãos adotivos, encara a morte do "velho Simeão", que os adotara. Após a morte de "dona Belisária", esposa de Simeão, eles passaram a viver em um mundo de violência e repressão, como evidenciado no texto e destacado por Gomes ${ }^{15}$ (2018). Após três anos de "guerra surda" (RUBIÃO, 2010, p.65), o "velho Simeão" morre, e os habitantes da Casa do Girassol Vermelho comemoram dançando e dando vazão à violência e à sexualidade que foram reprimidas de forma inflexível pelo pai adotivo, que se descrevia como sendo um "homem de moral rígida" (RUBIÃO, 2010, p.64), que não permitia "imoralidades" em seu lar.

Depois de pisar "na memória do velho Simeão, escarrando no passado" (RUBIÃO, 2010, p.65), os jovens continuam sua comemoração em um açude próximo à Casa do Girassol Vermelho. Nesse lugar, Xixiu, que traz constantemente a memória e as palavras de Simeão à tona e que "não abre mão da moral castradora" (GOMES, 2018, p.86) do pai adotivo, desaparece. Após o ocorrido, o grupo se desestrutura, uma vez que essa personagem era responsável por incitar a violência que os movia e, estranhamente, os reunia. De acordo com Gomes (2018), a Casa era sustentada pelos homens violentos ${ }^{16}$, Simeão e Xixiu, agora ausentes. No final da história, Belinha engravida, porém o

15 Gomes (2018) refere-se a Simeão como o "rígido padrasto que os [os jovens da Casa do Girassol Vermelho] submetera a proibições e violências" (p.85).

16 "[...] a Casa do Girassol Vermelho sobrevivia graças a uma força destrutiva e sedutora" (GOMES, 2018, p.87). 
que cresce em seu ventre não é uma criança, mas "um minúsculo girassol vermelho" (RUBIÃO, 2010, p.67). Constata-se, então, que o insólito, prenunciado no título do texto, se admitimos a Casa como entidade humanizada, é coroado no desfecho da narrativa.

Em "Alfredo", diferentemente do que se possa pensar, a personagem-título não é um homem, mas um dromedário, o que, mais uma vez, anuncia o insólito no pórtico do texto. Temos um nome, embutindo o gênero, e um engano em relação ao elemento nomeado, que não corresponde, inicialmente, a um ser humano, como parece, mas a um animal antropomorfizado. É imediata a dúvida de por que Rubião optou por dar a um dromedário o nome de um ser humano.

Conforme a história se desenvolve, percebemos que Alfredo nem sempre foi um animal. Convencido "da impossibilidade de conviver com seus semelhantes" (RUBIÃO, 2010, p.70), ele decide transformar-se em um porco. No entanto, não encontrou a paz e a tranquilidade que parecia procurar incessantemente. Definiu, então, que seria o verbo "resolver", porém, "não teve descanso, resolvendo assuntos, deixando de solucionar a maioria deles" (RUBIÃO, 2010, p.70). E converteu-se em dromedário, "esperando que beber água o resto da vida seria um ofício menos extenuante" (RUBIÃO, 2010, p.70).

Desse modo, Alfredo é composto como uma personagem que está sempre tentando se adaptar às realidades em que se insere, metamorfoseando-se em verbo e, posteriormente, animal. Contudo, nunca parece ter sucesso, conservando, em todas as suas transformações, seu nome, único aspecto que apresenta 
constância. É importante destacar que, mesmo em sua forma de dromedário, continua a experimentar sentimentos humanos, uma vez que foi figurado como um ser angustiado e resignado. Além disso, é capaz de falar e de se comunicar com seres humanos, como seu irmão, por exemplo, que sentiu "a ternura que emanava dos seus olhos infantis" (RUBIÃO, 2010, p.68).

Notamos, então, como os procedimentos discursivotextuais de composição da personagem enunciados no título são relevantes para uma leitura crítica do texto. Rubião compôs um dromedário que parece estar no meio de uma crise existencial e que, apesar de não ter mais o corpo de um ser humano, continua a sofrer como se ainda fosse um deles. A personagem que cumpre a função de narrador, o irmão de Alfredo, relata, no início do conto, que havia começado a escutar, constantemente, os gemidos de um animal. Segundo ele, nesses sons "vinha uma mensagem opressiva, uma dor de carnes crivadas por agulhas" (RUBIÃO, 2010, p.68). A personagem resolve, então, investigar a procedência dos ruídos. É dessa maneira que reencontra o irmão, na forma de dromedário. Sua esposa, contudo, não aceita a presença do animal em sua casa. Assim, os dois, resignados, partem em busca de algo ou de algum lugar que possa amenizar o desespero e a inquietude que os assolam.

Em "Marina, a Intangível", temos o nome da personagem - "Marina" - seguido de um adjetivo - "Intangível" -, que o modifica. Trata-se de uma personagem feminina, que não se consegue tanger, não se pode tocar; que passa imperceptível, cujas características não são suficientes para ser percebida ou 
entendida, podendo enganar a percepção ou o entendimento ${ }^{17}$. Uma vez que essa predicação foi realçada logo no título da narrativa, seus sentidos devem ser levados em conta na leitura dos procedimentos de composição. Semelhante a "A Casa do Girassol Vermelho", "Intangível" será sempre grafada com um "i" maiúsculo, o que importa de maneira especial.

Neste conto, José Ambrósio, um jornalista que trabalha no plantão noturno de um periódico, sofre com um bloqueio criativo, que o impossibilita de escrever. Até que um homem aparece na janela desse local, dizendo ter versos para publicar, que teriam sido encomendados pelo próprio José Ambrósio. Trata-se de um poema para Marina, a Intangível. Talvez haja uma correlação entre Marina e o texto que a personagem tenta redigir, já que tanto ela, quanto o texto parecem ser intangíveis. Além disso, percebe-se um caráter metalinguístico na narrativa, como podemos observar no trecho a seguir:

Ele as foi desfolhando com certa lentidão, muito compenetrado do trabalho. Rasgou as pétalas, pela metade, e colocou-as no chão. Formou palavras que não cheguei a decifrar e, em voz baixa, concluiu:

- Os primeiros cantos são feitos de rosas despetaladas. Lembram o paraíso antes do pecado. (RUBIÃO, 2010, p.74)

Em dado momento, a própria Marina chega ao prédio do jornal, no meio de uma procissão que lembra, em muitos aspectos, as religiosas, mas que também inclui linotipos, "letras manuscritas e garrafais" (RUBIÃO, 2010, p.75), sobrelevando, outra vez, a

17 INTANGÍVEL. In: DICIO, Dicionário Online de Português. Porto: 7Graus. In https:// www.dicio.com.br/intangivel/ Acesso em: 21.Set.2020. 
manifestação do insólito nas narrativas de Rubião. Ademais, "Marina, a Intangível" era "escoltada por padres sardentos e mulheres grávidas" (RUBIÃO, 2010, p.75). A personagem-título do conto é figurada como uma entidade, alguém digna de ser cultuada. Esse estatuto divino, que participa da composição de Marina, explicaria a grafia de "Intangível" com um "i" maiúsculo, além de reforçar sua condição de ser inacessível.

A descrição desse "cortejo" causa uma sensação de surpresa e choque, o que é condizente com a visão de Cardoso (2007, p.38), segundo a qual, na obra de Murilo Rubião, somos apresentados a "recortes de uma realidade que causa espanto, estranhamento". No final do texto, José Ambrósio se descobre sozinho no local, porém o poema de Marina estava pronto, "feito de pétalas rasgadas e sons estúpidos" (RUBIÃO, 2010, p.75).

Em "Os três nomes de Godofredo", o título do conto é, em si, um procedimento que antecipa a figuração da personagem-título. Nele temos um nome próprio no gênero masculino - "Godofredo" -, que integra uma locução adjetiva, "de Godofredo", com valor de posse, e sabemos que esse sujeito detém "três nomes". Ao longo da narrativa, passamos a saber que esses nomes são João de Deus, Robério e Godofredo. Cada nome equivale a uma vida da personagem, implicando alterações em sua personalidade, logo, sua figuração é múltipla e transmutável.

O texto se inicia com Godofredo - João de Deus nesse momento específico da narrativa - em um restaurante, sentado à mesa com uma mulher, aparentemente, estranha. Contudo, descobre tratar-se de sua segunda esposa, já que a primeira ele 
"matou num acesso de ciúmes" (RUBIÃO, 2010, p.77). A partir desse momento, é tomado pela curiosidade de saber mais detalhes sobre o relacionamento dos dois. Ele não tem, contudo, qualquer pretensão em descobrir os pormenores do assassinato da primeira esposa, já que não desejava que lhe "criassem o remorso de um assassinato do qual não tinha a menor lembrança" (RUBIÃO, 2010, p.77).

Assim, por meio da construção da narrativa, percebemos que Godofredo, que prefere ignorar o fato de que matou alguém, é um homem frio, agressivo e ciumento. Quando a vida com a esposa começa a cair na rotina, resolve assassiná-la. Desse modo, a personagem-título é figurada, também, como volúvel, uma vez que todas as características da mulher que lhe pareciam agradar desaparecem de um dia para o outro e, na sua opinião, tornam-se um aborrecimento.

É importante evidenciar que todos os traços da esposa que passam a the incomodar não eram revelados ou eram relevados, visto que sempre se impressionava e encantava pela beleza da mulher. Além disso, dentro da volatilidade e da multiplicidade de suas personalidades há uma constância. $\mathrm{O}$ tempo na narrativa $e$, consequentemente, na vida da personagem-título foi construído de forma cíclica. Ao longo do texto, Godofredo continua a encontrar outras mulheres com quem mantém algum tipo de relacionamento. $\mathrm{O}$ aspecto físico de todas elas era semelhante e, a cada novo encontro, seu nome mudava. O destino final desses relacionamentos era o mesmo: Godofredo acabava assassinando-as, o que confirma aspectos da figuração da personagem-título. 
Em "Memórias do contabilista Pedro Inácio", há um procedimento comum a "O pirotécnico Zacarias" e a "O exmágico da Taberna Minhota", que é a referência à ocupação da personagem-título - "ex-mágico", "pirotécnico" e "contabilista" -, outro comum a "Os três nomes de Godofredo", em que o nome próprio da personagem, no gênero masculino, é núcleo de uma locução adjetiva com valor de posse - "de Godofredo" e "do contabilista Pedro Inácio" - e, ainda, um terceiro procedimento, comum em quase todos os contos de Rubião, que é o emprego de um nome próprio.

Na composição desse título verifica-se um caráter acional, já que Pedro Inácio narra acontecimentos de sua vida, suas memórias, relacionando o relato, de uma maneira ou de outra, ao seu ofício de contabilista. A palavra "contabilista" tem um valor de predicação, visto que modifica o substantivo próprio "Pedro Inácio". A referência à profissão da personagem é extremamente significativa para a compreensão da história e dos procedimentos textuais envolvidos na figuração da personagem-título.

Neste texto, o narrador relata como todos os seus antepassados padeceram de um mesmo mal: o amor. Pedro Inácio, que estaria fadado a esse destino por questões hereditárias, exemplifica seu argumento ao expor que o amor de Jandira lhe custou "sessenta mil-réis de bonde, quarenta de correspondência, setenta de aspirina e dois anos de completo alheamento ao mundo" (RUBIÃO, 2010, p.81), além de, segundo ele, ter sido a causa de sua calvície.

Na narração de suas memórias, a personagem sempre associa seus relacionamentos a números, quantias monetárias, referências à 
contabilidade, o que nos leva a considerar a importância da profissão da personagem como elemento interveniente em sua figuração. Apesar de se descrever como um homem sentimental, que sofre por amor, Pedro Inácio tem uma mentalidade calculista, característica que está, sem dúvidas, relacionada à profissão desempenhada no mundo possível ficcional que habita. Assim, fica nítida a relevância do destaque desse processo figurativo no título do conto.

No final do texto, após dar detalhes a respeito de como o amor acabou por vitimar a maioria de seus ancestrais, Pedro Inácio descobre que não é filho biológico dos pais que conheceu a vida toda. Há, em seguida, uma quebra de expectativa, visto que esperamos que o narrador se decepcione após constatar a verdade sobre sua origem. No entanto, ele lamenta por todo o dinheiro que gastou em seus "estudos genealógicos" (RUBIÃO, 2010, p.84), pelo fato de não saber a causa de sua "vocação para o amor" (RUBIÃO, 2010, p.84) e o motivo de sofrer de calvície.

Percebemos que a personagem foi composta com elementos de referencialidades contraditórias, visto que declara ser vítima de um "sentimentalismo [que] era hereditário" (RUBIÃO, 2010, p.81), mas cujas ações desmentem essas características. A preocupações de Pedro Inácio parecem ser, exclusivamente, questões financeiras e descobrir a origem de sua calvície.

Em "Bruma (a estrela vermelha)"18, a personagem-título surge com seu apelido - "Bruma" -, pois seu nome era Dora, gênero 18 Em 1953, Rubião publicou seu segundo livro, A estrela vermelha, com apenas quatro contos, dentre os quais, "A estrela vermelha". Em A casa do girassol vermelho, publicado em 1978, esse conto passa a se intitular "Bruma". A composição "Bruma (a estrela vermelha)" não é pacífica, tendo havido variações ao longo de muitas outras publicações seguintes. Vamos, contudo, conforme a edição utilizada para este trabalho, respeitar a escolha editorial e seguir "Bruma (a estrela vermelha)". 
feminino, seguido, entre parênteses, de uma expressão de caráter apositivo - "a estrela vermelha". O fato de Rubião ter optado por Bruma, e não pelo nome de batismo da jovem é significativo e, portanto, merece consideração. Bruma, no sentido figurado, significa "o que dificulta o entendimento claro de alguma coisa; o que é vago, que não se compreende facilmente"19. No conto, a personagem-narrador, Godofredo, tem dificuldades de compreender seu irmão, Og, que diz ser capaz de ver astros coloridos, como uma estrela vermelha, em plena luz do dia. Godofredo, inclusive, reage com uma violência desmedida diante dos relatos de Og. Bruma ou Dora, irmã de criação dos dois, por outro lado, é sempre compreensiva e amorosa, o que desperta os ciúmes de Godofredo, que responsabiliza a moça pela loucura que acredita acometer o irmão. Assim, diante da nebulosidade com a qual a personagem-narrador encara o que o irmão enxerga com tanta clareza, conseguimos inferir a razão pela qual Rubião optou por destacar o apelido da personagem-título, e não seu nome.

Bruma sempre acompanha Og nas caminhadas nas quais ele testemunha a "estrela vermelha". A aparição do astro misterioso talvez esteja condicionada à presença da personagem em questão, já que, ao mesmo tempo, ela é responsável, indiretamente, pelo fato de Godofredo não conseguir ver a estrela. O ciúme que este sente da moça dificulta a compreensão de algo que seu irmão enxerga com muita clareza. Bruma condena explicitamente a violência e a intolerância que ele reserva ao irmão, o que apenas o deixa ainda mais irado.

19 BRUMA. In: DICIO, Dicionário Online de Português. Porto: 7Graus. Disponível em: https://www.dicio.com.br/bruma/. Acesso em: 22.Set.2020. 
Nesse sentido, podemos considerar que os sentimentos de Godofredo por Dora funcionavam como uma "bruma", que o impedia de enxergar o que Og via de forma nítida. Quando Og vai ao consultório de um psiquiatra, acompanhado pelo irmão e por Bruma, o médico não se surpreende com os seus relatos, mas reprova as reações violentas de Godofredo. Então, assustado, este acaba fugindo do consultório, deixando Bruma e Og no local. Alguns dias depois, tomado por "saudade e remorso" (RUBIÃO, 2010, p.87), decide ir procurar os dois. Entretanto, o prédio em que se localizava o consultório desapareceu. É somente após esse momento, desesperado em uma "inútil e angustiante busca" (RUBIÃO, 2010, p.88), que Godofredo pôde, finalmente, ver a estrela vermelha. Ele enxerga o astro no lote do prédio em que havia deixado Bruma e o irmão, o que corrobora a hipótese de que a aparição da estrela estivesse condiciona à personagem-título.

Em "D. José não era", encontramos o nome próprio da personagem-título - "José", no masculino, com a anteposição da abreviatura de um título nobiliário - "D.", que equivale a Dom -, seguido de uma expressão acional negativa - "não era". D. José é o agente de uma ação que não se realiza.

A narrativa é centrada na história de "d. José", um homem que perdeu os cinco filhos, "vítimas da tuberculose" (RUBIÃO, 2010, p.90), e cuja esposa "detestava-o" (RUBIÃO, 2010, p.89). Desse modo, os procedimentos textuais utilizados para compor a personagem nos dão um vislumbre de um homem triste, marcado pela perda dos filhos, pelo ódio da mulher e pelas especulações que "os habitantes do lugar" (RUBIÃO, 2010, p.89) faziam a respeito de sua vida. 
Um dia, ele decide se enforcar, e, ao se depararem com a cena, os vizinhos alegam ser fingimento, uma zombaria. O narrador afirma, então, que "todo o mundo fingiu não saber" (RUBIÃO, 2010, p.90) por que "d. José" havia se suicidado. Algum tempo após o ocorrido, uma estátua é erguida em sua homenagem, com os dizeres: "D. José, nobre espanhol e benfeitor da cidade" (RUBIÃO, 2010, p.90). Há, então, uma quebra de expectativa, como podemos constatar: "Derradeira mentira. D. José era um pobre-diabo e não possuía nenhum título de nobreza. Chamavase Danilo José Rodrigues" (RUBIÃO, 2010, p.90).

Essa quebra de expectativa torna evidente que o "d. José" do título não se referia a um Dom José, mas a uma pessoa comum, sem "nenhum título de nobreza". O próprio título do conto já nos orienta para isso, com a informação de que "d. José não era". A personagem foi figurada como o agente de uma ação, na sentença negativa, em relação à qual sua condição era incompatível. $O$ fato de "d. José" ser sempre grafado com um "d" minúsculo, a não ser nos casos em que inicia um período, denuncia essa sua incapacidade de ser Dom ${ }^{20}$.

Essa escolha do autor é extremamente significativa, uma vez que Danilo José, nome composto da personagem, perde a sua identidade para virar outra pessoa, completamente diferente de quem, de fato, era. Também podemos associar essa opção de Rubião à forma impiedosa e cruel com que os habitantes da cidade tratavam o protagonista da história. Ele só se torna alguém "D. José, nobre espanhol e benfeitor da cidade" (RUBIÃO, 2010, p.90)

20 Cabe aqui realçar recurso inverso que já destacamos em "A Casa do Girassol Vermelho" ou em "Marina, a Intangível". 
- após sua morte. Constatamos, então, que o "D. José" do título não era o Danilo José arquiteturado por Rubião, que "amava o povo", que, em contrapartida, "observava-o com ferocidade" (RUBIÃO, 2010, p.90).

Igualmente às motivações advindas da leitura interpretativa do texto, que nos levaram a admitir a existência de personagem-título em "A Casa do Girassol Vermelho", fomos levados à semelhante admissão no conto "A Lua". Nesta narrativa, a personagemnarrador, um homem que não é nomeado, cumpre sua missão de "vigiar os passos de Cris" (RUBIÃO, 2010, p.91) todas as noites, sob absoluta escuridão. Em determinada ocasião, Cris muda seu itinerário costumeiro, parando em frente "a uma casa baixa, a única da cidade que aparecia iluminada" (RUBIÃO, 2010, p.92). Nesse momento, o narrador o atingiu com um punhal nas costas, e "do seu corpo magro saiu a lua" (RUBIÃO, 2010, p.92). Fomos então levados a acreditar que a lua e Cris sejam um mesmo elemento, uma mesma personagem. Desde o início do conto, o narrador vinha destacando, a todo instante, o estado de escuridão completa que caracterizava suas noites de perseguição, como se podemos ler: "Nem luz, nem luar. O céu e as ruas permaneciam escuros, prejudicando, de certo modo, os meus desígnios" (RUBIÃO, 2010, p.91).

O único momento da narrativa em que essa situação de breu é modificada é no instante em que, após mudar seu itinerário de costume, Cris para em frente à única casa iluminada da cidade. A lua, que saiu "do seu corpo magro" (RUBIÃO, 2010, p.92), simbolicamente, traz de volta a luz do luar, que ilumina os arredores. Assim, podemos considerar a lua como uma personagem-título, pois ela estaria representada no título em substituição ao nome 
Cris, que a mantinha escondida dentro de si. O procedimento textual utilizado em sua composição foi o recurso a uma figura antropomorfizada. A lua não apenas apresenta atributos humanos, mas assume a forma humana. Corporificada, passa a ter rotina, a caminhar todos os dias, durante a noite, pelos mesmos lugares.

Em "O homem do boné cinzento", temos uma expressão indicativa de gênero, sexo e, podemos arriscar desde o título, que de recorte etário - "o homem", porque não o menino, nem o velho - seguida de uma locução adjetiva que o distingue descritivamente - "do boné cinzento", ou seja, aquele que tem por marca própria o uso de um boné da cor cinza. A história é relatada por um narradorpersonagem, Roderico, que conta como a chegada de um novo vizinho à rua em que morava trouxe "intranquilidade" (RUBIÃO, 2010, p.105) aos demais habitantes do local.

Esse novo residente permanece uma fonte de mistério durante toda a narrativa, uma vez que só era visto em um determinado horário todos os dias. O "tempo restante conservava-se invisível" (RUBIÃO, 2010, p.105). Nesses momentos, o sujeito, sempre portando seu boné cinzento, apenas "tirava baforadas do cachimbo e se recolhia novamente" (RUBIÃO, 2010, p.105).

Em um primeiro momento, o novo vizinho não é nomeado, o que nos leva a refletir que a identidade da personagem em questão não é fator determinante neste conto. O procedimento textual de dar um nome às personagens é extremamente significativo, assim como o é omitir esse aspecto composicional. Só nos é possível descobrir que "o homem do boné cinzento" chama-se Anatólio no meio da narrativa, quando o irmão de Roderico, que 
estava completamente obcecado pelo novo vizinho, revela essa informação ao narrador.

A personagem-título, o homem do boné cinzento, é envolta em uma atmosfera de mistério durante todo o texto. Desde o princípio, ela é responsabilizada por acontecimentos insólitos que marcarão a narrativa, uma vez que o narrador deixa claro que "o culpado foi o homem do boné cinzento" (RUBIÃO, 2010, p.105), frase que abre a narrativa. É importante destacar que a personagem-título parecia ciente da comoção que causava entre os vizinhos, uma vez que, em suas aparições diárias, "às vezes mostrava um sorriso escarninho" (RUBIÃO, 2010, p.106).

Assim, Anatólio, que só era visto em frente à sua casa, portando seu boné cinzento, no mesmo horário diariamente, é figurado como o responsável pela "intranquilidade" (RUBIÃO, 2010, p.105) que começou a atormentar os demais moradores da rua antes mesmo desse sujeito enigmático chegar ao lugar. Essa inquietação teve início quando as personagens foram despertadas "por desusado movimento de caminhões, a despejarem pesados caixotes no prédio do antigo hotel" (RUBIÃO, 2010, p.105), futura residência dessa personagem. Tal sentimento permanece mesmo depois que o homem, após emagrecer espantosamente, desaparece por completo, em mais uma manifestação do insólito, restando apenas "a cabeça, coberta pelo boné" (RUBIÃO, 2010, p.107).

Roderico percebe que o corpo do irmão "diminuíra espantosamente" (RUBIÃO, 2010, p.107), até o ponto em que ele se transforma em uma "bolinha negra" (RUBIÃO, 2010, p.107). Desse modo, mais do que o próprio Anatólio, o boné cinzento, conservado 
mesmo quando seu dono desaparece por completo, parece ter relação com os demais eventos insólitos da narrativa. A inquietação que teve início com a mudança dessa personagem para a rua em que o narrador morava perdura mesmo após o seu sumiço.

Em "Mariazinha", temos um dos mais elementares de todos os procedimentos de figuração de personagens, que é o emprego do nome próprio - Maria21 -, embutindo a indicação do gênero feminino -, mas a opção pelo diminutivo leva a nuances que devem ser consideradas e que somente se revelam a partir da leitura integral do texto.

Mariazinha tem um papel determinante no desenrolar da história, visto que a "mulher é mais um elemento que compõe os insólitos da narrativa" (SILVA, 2007, p.65). Graças aos dispositivos discursivotextuais empregados por Rubião, percebemos que ela é figurada como alguém dissimulada, que transmite uma imagem de si mesma à sociedade incompatível com as ações que toma em sua vida privada.

A história começa em 1943, mas recua vinte anos no tempo, e "tudo recomeçou para os habitantes de Manacá" (RUBIÃO, 2010, p.108). Josefino Maria, que cumpre a função de narrador, relata as mudanças decorridas desse regresso no tempo: "couberam os anos passados, voltaram-me os cabelos e Mariazinha recuperou a sua virgindade" (RUBIÃO, 2010, p.108), alguns moradores da cidade ficaram insatisfeitos com a falta de calçamento das ruas e outros, inconformados por perderem os filhos, "recolhidos aos ventres maternos" (RUBIÃO, 2010, p.108).

21 Um diálogo mais denso dessa narrativa com o conjunto da obra de Rubião, tendose em conta muitas de suas epígrafes bíblicas, pode, talvez, permitir que se compare o nome da personagem - Maria - ao nome da Virgem Maria, ideia que, de certa maneira, já permeia nossa leitura, ainda que não desenvolvida neste momento. 
O homem que teria seduzido Mariazinha, Zaragota, "seria enforcado na torre da igreja" (RUBIÃO, 2010, p.109). A jovem, por outro lado, "extasiada com os seus novos quinze anos" (RUBIÃO, 2010, p.109), fica noiva de Josefino Maria por ordem do agora bispo da cidade. Diante da necessidade de punição para o homem que seduzira Mariazinha, percebemos como os demais moradores de Manacá a visualizam como alguém que simboliza a inocência, mas que foi desvirtuada por uma figura aproveitadora. A opinião do narrador, contudo, já revela o verdadeiro caráter da moça. Josefino Maria classifica como "infeliz" (RUBIÃO, 2010, p.108) o mês em que conheceu Mariazinha. O casamento não se realiza, e os cidadãos revoltam-se porque "Mariazinha fora seduzida novamente e o sedutor fugira" (RUBIÃO, 2010, p.110).

No entanto, "ao contrário do que ardilosamente tinham anunciado" (RUBIÃO, 2010, p.110), Josefino Maria é que havia sido seduzido por Mariazinha. O papel da moça foi o de agente da ação, e não o de paciente. Desse modo, o narrador, convencido de que a noiva "era uma depravada" (RUBIÃO, 2010, p.110), decide cometer suicídio, e testemunhamos o seu enterro no desfecho, quando a história avança no tempo, novamente, para 1943.

Assim, podemos constatar que, apesar de tentar transmitir uma imagem vinculada à inocência, as ações de Mariazinha são incompatíveis com essa ideia de virtude que a personagem procura demonstrar, o que a representa como uma figura ardilosa e dissimulada. Além disso, podemos considerar o uso do diminutivo em seu nome como uma tentativa de reforçar a inocência juvenil que, aparentemente, sempre esteve ausente na mulher. 
Em "Elisa", repetem-se, basicamente, os mesmos procedimentos de "Bárbara" e, em parte, de "Mariazinha", com o emprego do nome próprio, comum ao gênero feminino.

A história se inicia com a personagem-narrador relatando a chegada de uma completa estranha à sua casa, que "empurrou com naturalidade o portão que vedava o acesso ao pequeno jardim, como se obedecesse a hábito antigo" (RUBIÃO, 2010, p.111). Essa figura misteriosa, a personagem-título, é fundamental para a instauração do insólito, como adverte Luciana Morais da Silva22 (2007). Elisa permanece uma incógnita durante toda a narrativa, pois as ações que exerce ao longo da história corroboram a hipótese de que ela teria algum "segredo" (RUBIÃO, 2010, p.111). Podemos considerar que o seu hábito de reclusão confirme isso, já que "raramente saía e nunca aparecia à janela" (RUBIÃO, 2010, p.111). Além disso, ela também nada conta ao narrador e à sua irmã, Cordélia, a respeito de sua origem ou dos "acontecimentos [que] abalaram a sua vida" (RUBIÃO, 2010, p.111), e essas duas personagens, em momento algum, questionam ou estranham a presença da "desconhecida" (RUBIÃO, 2010, p.111) em seu lar, acolhendo-a sem ao menos saberem seu nome.

A "desconhecida" (RUBIÃO, 2010, p.111) se adaptou rapidamente à rotina de seus anfitriões "e, no rosto, já estampava uma alegria tranquila” (RUBIÃO, 2010, p.111). É importante destacar que, quando Elisa chega à sua casa, o narrador a descreve como aborrecida, e a mudança em sua percepção é relevante do ponto de vista da figuração da personagem-título. No curto período em

22 "[A] narrativa foge à ordem do que se considera comum: o fato de alguém chegar dessa maneira em uma residência" (SILVA, 2007, p.112). 
que permaneceu na casa, afastada de seu "segredo" (RUBIÃO, 2010, p.111) e de qualquer menção a ele, viveu em relativo estado de felicidade. Cordélia e seu irmão se dedicavam à hóspede, visto que o narrador destaca que ela era "alguém que necessitava de nossos cuidados, do nosso carinho" (RUBIÃO, 2010, p.111). Elisa, contudo, abandona-os sem dar quaisquer explicações, possivelmente pelo fato de a personagem-narrador ter lhe dado uma resposta negativa quando lhe perguntou se já havia amado alguma vez. Podemos, com isso, inferir que ela pode ter começado a desenvolver sentimentos românticos e que, talvez, o mistério que a envolvesse estivesse ligado a algum tipo de desilusão amorosa.

Após um ano desaparecida, sem dar notícia alguma, Elisa reaparece e é novamente recebida sem estranhamento algum. Nesse momento, a personagem-narrador encontra-se "intranquilo" (RUBIÃO, 2010, p.112). Apaixonado por Elisa, não sabe como declarar seus sentimentos e teme uma nova fuga da amada, o que se concretiza alguns meses depois. Há um aspecto determinante nesse novo desaparecimento. Ela partiu, mas disse à personagemnarrador e à sua irmã o seu nome. Assim, "como lhe ficasse sabendo o nome" (RUBIÃO, 2010, p.112), o narrador propõe à Cordélia que os dois mudem de endereço. Ela, então, questiona:

- E Elisa? Como poderá encontrar-nos ao regressar? Refreei a custo a angústia e repeti completamente idiotizado:

- Sim, como poderá? (RUBIÃO, 2010, p.112).

Esse pequeno diálogo é extremamente interessante para a compreensão da trama. Cordélia dá como garantido o retorno de 
Elisa, cujas aparições e fugas contínuas, sem motivos aparentes, marcam o caráter ciclicamente insólito da narrativa. A personagemnarrador, apesar de amar Elisa, parece não estar mais disposto a tolerar os sumiços sem explicações, agora que um pouco do mistério envolto em sua figura desapareceu com a revelação de seu nome.

Em "A noiva da Casa Azul", um sintagma nominal - "A noiva" -, no gênero feminino, é qualificado por um sintagma adjetival - "da Casa Azul". Tal processo se assemelha ao que verificamos em "O ex-mágico da Taberna Minhota".

A história começa com a personagem-narrador dizendo por que estava em um trem que tinha como destino Juparassu. Conforme conta, "a culpa era de Dalila" (RUBIÃO, 2010, p.113), que "na véspera de partir do Rio dançara algumas vezes com o ex-noivo" (RUBIÃO, 2010, p.113). Então, o narrador decide surpreender a namorada com um pedido de casamento.

A cidade de Juparassu e Dalila parecem convergir em certas características enunciadas pelo narrador, uma vez que, depois que beijou a moça pela primeira vez, "nunca Juparassu apareceu tão linda e nunca as suas serras foram tão azuis" (RUBIÃO, 2010, p.114). Assim, faz sentido que, ao chegar ao lugar e se deparar com seu aspecto deteriorado, "as casas de campo estão em ruínas" (RUBIÃO, 2010, p.114), descubra que a amada não esteja mais viva. Assim como Dalila, Juparassu também morreu.

Resolve conversar com um colono, que vivia no lugar desde criança, "à espera de uma palavra salvadora que desfizesse o pesadelo" (RUBIÃO, 2010, p.115). Suas esperanças, entretanto, são frustradas. O homem conta "que o rapaz daquela casa fora levado 
para Minas com a saúde precária" (RUBIÃO, 2010, p.115), e é ele quem revela a morte de Dalila. O interessante nesse diálogo, no que diz respeito à figuração da personagem-título, é que o colono não reconhece Dalila apenas pelo seu nome, o protagonista precisa "explicar-lhe que se tratava da moça da Casa Azul" (RUBIÃO, 2010, p.115). A jovem estava relacionada ao seu lugar de procedência de tal forma que a causa de sua morte estava ligada ao motivo da ruína do local, "a decadência da região se iniciara com uma epidemia de febre amarela, a se repetir por alguns anos, razão pela qual ninguém mais se interessou pelo lugar" (RUBIÃO, 2010, p.115). Apesar de o motivo da morte de Dalila não estar completamente explícito no texto, podemos inferir que a moça foi vítima de tal epidemia. Quando a personagem-narrador chega à sua casa, constata que dela "restavam somente as paredes arruinadas, a metade do telhado caído, o mato invadindo tudo" (RUBIÃO, 2010, p.115).

Como o "ex-mágico", Dalila é a ex-namorada, a ex-quase noiva, e sua morte - ainda que não acontecida no plano das ações ratifica a condição de não ser mais - ou nunca ter sido de fato. Podemos ainda apontar uma correlação com "A Casa do Girassol Vermelho", uma vez que o sintagma adjetival "Casa Azul" é sempre grafado com letras maiúsculas, o que, nesse conto em particular, nos permite inferir uma simbiose entre Dalila e a casa, conforme sugerido pelo percurso narrativo.

Em "O bom amigo Batista" podemos observar o sobrenome da figura - "Batista", cujo nome é João -, antecedido de uma locução adjetival no gênero masculino - "O bom amigo" -, em que tanto o adjetivo "bom", quanto substantivo "amigo" - que também pode exercer funções próprias de adjetivo - predicam-no positivamente. 
Assim, poderíamos inferir que Batista desempenharia ações dignas de um "bom amigo". Contudo, nenhuma das atitudes de Batista o caracteriza como um "bom amigo".

José, o narrador, relata sua amizade com João Batista, "o melhor amigo" (RUBIÃO, 2010, p.117) que já teve, desde os dias de infância. Quando crianças, Batista copiava os exercícios escolares de José (RUBIÃO, 2010, p.117), na adolescência, roubou uma de suas namoradas (RUBIÃO, 2010, p.118) e, na fase adulta, precisou de seu auxílio "na prova de matemática, matéria da qual ele não tinha grandes conhecimentos" (RUBIÃO, 2010, p.118), quando os dois prestaram concurso para o Ministério da Fazenda. Os dispositivos discursivo-textuais empregados na composição de Batista permitem caracterizá-lo como uma figura egoísta e aproveitadora, mesmo que a história seja narrada pelo ponto de vista de José, que não percebe os abusos aos quais o "bom amigo" o submete de forma recorrente.

Por meio dos relatos de José, que, apesar de narrar acontecimentos de sua vida, sempre o faz como pano de fundo para falar de sua "amizade" com Batista, construímos uma imagem da personagem-título como alguém preguiçoso, aproveitador, dissimulado, que explora um "amigo", manipulando-o como lhe convém, que não se importa de usar os outros para subir na vida. Os processos de figuração de Batista, ao longo do texto, contradizem o modo como aparece prenunciado no título.

Com o desenrolar da narrativa, José acaba em um hospício após fingir-se de doido (RUBIÃO, 2010, p.119). Essa foi a solução encontrada por ele para "escapar aos insultos" (RUBIÃO, 2010, p.119) 
da esposa. Como o próprio José deixa claro, ele sempre teve por hábito evitar o confronto (RUBIÃO, 2010, p.119). No final do texto, a personagem-narrador descobre que Batista e a esposa estão vivendo como um casal. Obviamente, José já tem uma explicação para o ocorrido, como podemos constatar no trecho que encerra o conto: "Naturalmente, Batista descobriu que minha mulher planejava retirar-me daqui e, para evitar que tal acontecesse, foi ao extremo da renúncia, atraindo-a para si. Pobre amigo" (RUBIÃO, 2010, p.120, grifo nosso).

Em "Epidólia", tornamos a ver o mais elementar dos procedimentos de figuração da personagem, que é o emprego do seu nome próprio, trazendo consigo a determinação de gênero, conforme já se deu, principalmente, em "Bárbara" e "Elisa" e, mesmo, em "Mariazinha" e "Alfredo", com suas particularidades.

O texto começa com Manfredo, o narrador, questionando onde estaria Epidólia, "se há poucos instantes a estreitava de encontro ao ombro?" (RUBIÃO, 2010, p.121). Ficamos sabendo que, anteriormente, o casal se encontrava sentado em um banco de parque, em estado de relativa tranquilidade. Entretanto, a narrativa se inicia e o insólito se manifesta. A moça desaparece de repente, sem deixar vestígio. Assim como em "O homem do boné cinzento" e em "Elisa", a personagem-título deste conto mantém-se fonte de mistério durante toda a história. Desaparecida desde o princípio, Epidólia não pode ser encontrada em momento algum, e a única informação concreta que Manfredo parece ter a seu respeito é o seu nome, conforme em "Elisa".

Decidido a procurar a amada, o protagonista vai até o hotel onde a jovem estaria hospedada. Lá, o gerente o informa que 
ela "costuma permanecer vários dias sem sair do hotel ou dele se ausenta por extensa temporada" (RUBIÃO, 2010, p.122). Essa informação a respeito de Epidólia é corroborada posteriormente pelo tio da jovem, que diz que "ela some e reaparece a cada experiência sentimental" (RUBIÃO, 2010, p.125). Assim, os dados referentes à amada que Manfredo consegue apontam para uma figura inconstante, que permanece de forma transitória e breve na vida dos homens com quem teria um envolvimento romântico, já que o casal se conhecia há apenas duas semanas. Epidólia possui "hábitos singulares" (RUBIÃO, 2010, p.122), determinados por suas vivências amorosas, e ela parece estar associada ao desenvolvimento do insólito no texto, que também atinge outras categorias da narrativa, além das personagens, como as de tempo e espaço.

Em "Petúnia", temos o apelido da personagem, já que seu nome é Cacilda, mas Éolo, seu marido, refere-se a ela pelo apelido, e isso importa para sua figuração. Trata-se de figura feminina, uma vez que tanto "Petúnia", quanto Cacilda, são nomes femininos.

Cacilda não é a única mulher na vida de Éolo a quem ele chama de Petúnia, pois ele também se refere assim às suas filhas - "três louras Petúnias enterradas na última primavera: Petúnia Maria, Petúnia Jandira, Petúnia Angélica" (RUBIÃO, 2010, p.127). Essas personagens merecem especial atenção, uma vez que podem ser consideradas elementos antropomorfizados. Como demonstra Silva (2016, p.115), Éolo é figurado, também, "como o pai de três flores mortas e renascidas a cada primavera".

Éolo, filho único de uma mulher, dona Mineides, que desejava casá-lo a qualquer custo, "não tinha planos para casamento" 
(RUBIÃO, 2010, p.127). No entanto, ao conhecer Cacilda, convenceuse "de que sempre amara Petúnia, porque na sua frente estava Petúnia" (RUBIÃO, 2010, p.129). No primeiro contato do casal, Cacilda parece compreender imediatamente o mundo de Éolo, composto, por exemplo, por pássaros que apenas ele podia ver. Esses animais povoavam sua casa e "invadiam as salas, voavam em torno dos lustres, pousavam nos braços das cadeiras" (RUBIÃO, 2010, p.128) sempre que os outros residentes estavam dormindo. Nos primeiros anos de casados, viviam tranquilos e felizes, com a residência "povoada de pássaros e cavalos-marinhos, estes trazidos pela noiva" (RUBIÃO, 2010, p.129).

Entretanto, alguns dias após o parto da última filha, os atritos entre o casal começaram. A maquilagem do quadro da mãe, que estava no quarto de Éolo e Cacilda, passou a derreter todas as noites, e o filho, sem questionamento algum, a retocar "o rosto de dona Mineides" (RUBIÃO, 2010, p.129). O comportamento de Cacilda, então, muda drasticamente, e ela começa a demonstrar irritabilidade e agressividade. Quando as filhas do casal morrem, a mulher culpa a sogra, a "megera" (RUBIÃO, 2010, p.130), que já estava morta, mas permanecia na vida das personagens graças ao referido quadro, que derretia diariamente ${ }^{23}$. Nesse ponto da narrativa, os cavalos-marinhos, que antes viviam em harmonia com os pássaros de Éolo, passam a ter a função de vigiá-lo e impedir que ele tenha qualquer tipo de contato com as filhas mortas. Eles representam, assim, a mudança da atitude de Cacilda em relação ao marido e à sua vida de casada.

23 Não vamos, neste momento, avançar na questão, mas esse mesmo procedimento se vê em "O homem do boné cinzento". 
Quando "descobriu que os pequenos animais tinham o sono tão profundo quanto o de Cacilda" (RUBIÃO, 2010, p.130), Éolo começou a esperar que todos estivessem dormindo para desenterrar as filhas diariamente, "transferidas de seus túmulos para um canteiro de açucenas" (RUBIÃO, 2010, p.130). A partir desse momento, cuida das meninas como se cuidasse de flores. Afinal, elas eram suas "Petúnias" (RUBIÃO, 2010, p.130), que dançavam, brincavam e faziam perguntas, como qualquer criança ${ }^{24}$. No desfecho, como evidencia Silva ${ }^{25}$ (2016), constatamos que a vida de Éolo será marcada pela repetição e pela perda da mãe, de suas filhas e da esposa, que ele mata no meio da narrativa.

Em "Aglaia", repete-se o nome próprio, indicando figura feminina. Ela é uma mulher jovem e rica, que se casa com Colebra "sob o regime de separação de bens" (RUBIÃO, 2010, p.132), única exigência de seu pai para a realização do matrimônio. 0 futuro marido, contudo, estipula uma outra condição: a ausência de filhos. Aglaia concorda, visto que "repugnava-Ihe uma prole" (RUBIÃO, 2010, p.132). A narrativa nos leva a perceber que as personagens estivessem "mergulhadas na busca pelo prazer" (SILVA, 2016, p.117).

Tanto Aglaia quanto Colebra são figurados como personagens imediatistas, que procuram viver o presente sem se preocupar com as consequências. $\mathrm{O}$ fato de recusarem a possibilidade de ter filhos de forma tão veemente indica que não admitirão possíveis empecilhos em sua busca incessante pelo prazer. A vida de casado

24 Por isso, podemos sugerir sua antropomorfização

25 "O humano, os contatos sociais e a convivência entre os seres são marcas colocadas em exposição na narrativa de Murilo Rubião, com um homem confrontado pela repetição e, de certo modo, pela perda" (SILVA, 2016, p.116). 
começa sem percalços, "tudo era festa e ruído na vida deles" (RUBIÃO, 2010, p.133). No entanto, "de repente houve uma ruptura violenta: cessaram as regras de Aglaia" (RUBIÃO, 2010, p.133). A partir desse momento, a mulher passa a engravidar sucessivas vezes, de forma ininterrupta, mesmo fazendo uso dos mais variados tipos de métodos contraceptivos ou evitando relações sexuais. Então, como as personagens são "profundamente centradas em si mesmas" (SILVA, 2016, p.119), a chegada de inúmeras crianças as distancia, já que destrói o elo que as unia, uma vida imediatista, centrada na satisfação de seus respectivos desejos.

Colebra é um homem extremamente ambicioso, que vê na esposa uma maneira de sair da vida de "pequenos empregos, dos biscates humilhantes" (RUBIÃO, 2010, p.134). Aglaia pode ser considerada a mulher que gesta a manifestação do insólito na narrativa. Ela dá à luz bebês que nem mesmo "se prendiam ao corpo materno pelo cordão umbilical" (RUBIÃO, 2010, p.135). Suas gestações são mais curtas do que o comum e, frequentemente, originam "ninhadas de quatro e cinco" (RUBIÃO, 2010, p. 135). Além disso, no início do relacionamento dos dois, ela parecia ingênua, ignorante em relação aos reais motivos que levaram Colebra ao matrimônio. Assim, como evidenciado por Silva ${ }^{26}$ (2016, p.117-118), as personagens são figuradas de forma conflitante no mundo possível ficcional armado por Rubião, "o oportunista e a dama inocente".

Em "O convidado", vemos um recurso ainda não utilizado nos demais textos. O vocábulo "convidado" tanto pode ser visto, a pelo prazer que, pelas vias dos novos discursos fantásticos, acaba por questionar os limites textuais, pondo em xeque o próprio mundo possível ficcional, em que o insólito se manifesta." (SILVA, 2016, p.117-118). 
princípio, como particípio do verbo convidar, quanto como adjetivo, tendo-se em vista sua origem no particípio, ou como substantivo, pela anteposição do artigo "o" que o determina. Trata-se de figura do gênero masculino, sujeito paciente - em qualquer das opções que façamos - da ação de convidar, e tal fato é importante para os processos composicionais de sua figuração.

O protagonista, José Alferes, recebe um convite insólito, que não mencionava "a data e o local da festa, [e que] omitia o nome das pessoas que a promoviam" (RUBIÃO, 2010, p.137). $\mathrm{Na}$ esperança de que a remetente fosse Débora, que estava hospedada no mesmo andar do hotel que o seu e por quem nutria interesse romântico, decide procurar um traje adequado para a ocasião. Mais tarde, entretanto, frustra-se ao descobrir que a mulher "viajou de férias" (RUBIÃO, 2010, p.139), porém, mesmo assim, decide comparecer ao misterioso evento. José Alferes é recebido pelo "comitê de recepção" (RUBIÃO, 2010, p.139), que constata a autenticidade do convite, mas admite que ele não seria o verdadeiro convidado, que ainda estaria sendo esperado (RUBIÃO, 2010, p.140).

A personagem a qual corresponderia "o convidado" não atua no nível diegético, mantendo a personagem-título envolta em mistério, sem que saibamos, sequer, se ela existe. Desse modo, a expectativa, construída ao longo do texto, de que venhamos a conhecer o verdadeiro convidado não se concretiza. Não temos muitas informações a seu respeito, pois as demais personagens que aguardam sua chegada, "não o conheciam, ignoravam o seu aspecto físico, os motivos da homenagem" (RUBIÃO, 2010, p.140). Apesar disso, "sem ele a festa não seria iniciada" (RUBIÃO, 2010, p.140). 
Em contrapartida, José Alferes, que também recebe um convite e comparece ao evento, é confundido diversas vezes com o convidado verídico. Ele também é sujeito paciente da ação implícita no título, ficando à deriva, sem compreender o que realmente está acontecendo. Todas as ações que ele consegue efetivamente exercer no texto estão relacionadas aos esforços de comparecer à festa. A partir do momento em que decide deixar - local, todas as suas tentativas são frustradas, e ele parece condenado, como as demais personagens, a esperar por alguém que pode nunca chegar.

Em "Botão-de-Rosa", o título é composto por uma expressão formada por um núcleo - "Botão", com valor propriamente substantivo - e uma locução - "de-Rosa", com valor propriamente adjetivo -, que corresponde ao apelido da personagem-título, no gênero masculino.

Nesta história, a personagem, inicialmente acusada de engravidar todas as mulheres da cidade, é presa. A denúncia, no entanto, é modificada para tráfico de heroína. Tal reviravolta espanta o defensor do protagonista, José Inácio, “a única pessoa a desconhecer que fora designado exclusivamente para dar aparência de legalidade ao processo" (RUBIÃO, 2010, p.145). Ressaltamos que Botão-de-Rosa parece resignado. É evidente, a partir de seu comportamento, que ele não vê motivos em acreditar que sua sorte possa mudar, pois sentia "que era um homem liquidado" (RUBIÃO, 2010, p.144). Como na maioria das demais narrativas, o insólito se instaura. A única personagem que, em um primeiro momento, se indigna com a situação é José Inácio. Botão-de-Rosa permanece extremamente pacífico e indiferente 
durante toda a história, sem questionar os rumos que seu destino toma. Somos levados a crer que se trate de alguém muito vaidoso.

Botão-de-Rosa aceita seu julgamento fraudulento e sua condenação absurda sem pestanejar. Entretanto, no início do texto, pressentindo que as autoridades invadiriam sua casa para buscá-lo, "escolheu para o dia o seu melhor traje" (RUBIÃO, 2010, p.144) e alisou "a barba com uma escova especial umedecida em perfume" (RUBIÃO, 2010, p.144). Ele nos faz lembrar uma figura messiânica, pois vestia uma "túnica branca" (RUBIÃO, 2010, p.144), tinha "longos cabelos" (RUBIÃO, 2010, p.144) e uma barba da qual cuidava com esmero. Essa caracterização é contundente, se levarmos em conta que aceitou seu destino sem qualquer tipo de questionamento ou protesto, com resignação e dignidade ${ }^{27}$.

O nome da personagem-título não é revelado em momento algum, recaindo sobre seu apelido toda a indicação à sua presença na diegese. A nomeação, contudo, é um procedimento composicional muito significativo, assim como o é a exclusão de tal estratégia textual. A existência de Botão-de-Rosa parece não ter importância, uma vez que a sua vida é sacrificada em um processo repleto de ilegalidades. Sendo o seu ser e a sua identidade também suprimidos.

Em "Os comensais", observamos uma personagemtítulo no plural, como em "Os Dragões", com carácter acional, semelhantemente a "O Convidado", mas cuja posição deixa de ser paciente para ser agente. A expressão aponta para figuras que se encontram sentadas conjuntamente à mesa ou que comem em 27 Não verificamos na tradição crítica possíveis comparações entre Botão-de-Rosa e Jesus Cristo, mas elas devem existir e, se não existem, fica-se a dever que se a façam, pois sua figuração aproxima-o da imagem de Cristo. 
grupo. Os comensais em questão são, majoritariamente, figuras masculinas, com exceção de Hebe, antiga namorada de Jadon, o protagonista, que aparece no meio da história.

Jadon costuma almoçar sempre no mesmo local, já que nesse refeitório the servem comida de qualidade, que era "sempre renovada sem que isso envolvesse qualquer sugestão ou pedido seu" (RUBIÃO, 2010, p.150). Contudo, a postura de seus companheiros o incomodava, pois eles "permaneciam quietos, os braços caídos, os olhos baixos" (RUBIÃO, 2010, p.150). Eles não se alimentavam, apesar de terem os pratos cheios substituídos a todo momento, e sempre se sentavam nos mesmos lugares. Jadon se perguntava por que nunca os vira chegar ou sair do local, uma vez que, ao entrar no refeitório, eles já estavam em suas respectivas posições de costume. Apesar de ele fazer de tudo para chamar a atenção desses outros comensais, até mesmo se valer de uma violência irracional, como apontado por Silva ${ }^{28}$ (2016), nunca obteve sucesso. O "segregamento que lhe impunham" (RUBIÃO, 2010, p.151) o transtornava, e Jadon não conseguia "penetrar na intimidade daqueles cavalheiros taciturnos" (RUBIÃO, 2010, p.150). Novamente, temos o insólito manifesto.

Os comensais são compostos como figuras apáticas, indiferentes e, até mesmo, fantasmagóricas ${ }^{29}$. Eles não reagem nem mesmo nos momentos de violência extrema do protagonista ou quando têm os pratos de comida ainda cheios repostos, o que só aumenta a ira de Jadon. Todas essas figuras parecem

28 "A ideia de fazer o outro reagir com o uso da brutalidade e da força é, por si mesma, equivocada e, em certo sentido, marcada pela privação da razão" (SILVA, 2016, p.136).

29 Será oportuno, adiante, ao avançar sobre os processos de composição dessas personagens, articular a leitura com as perspectivas críticas da fantasmagoria. 
ser jovens. Hebe, por exemplo, permanece com dezesseis anos, mesmo que trinta anos tenham se passado desde a última vez em que vira o antigo namorado. No final do texto, desesperado, Jadon resolve fugir do lugar, levando Hebe consigo. Contudo, fracassa. Encurralado e sem recordação alguma a respeito do que aconteceu, Jadon retorna à sala de jantar. Nesse momento, o protagonista parece ter regredido aos seus 20 anos, e seus olhos "perderam-se no vazio" (RUBIÃO, 2010, p.155). No desfecho, Jadon se torna um comensal como os outros.

O recurso à personagem-título aparece em vinte e seis contos dos trinta e três que compõem a obra de Murilo Rubião ${ }^{30}$. O processo discursivo-textual mais empregado para incluir elementos da figuração da personagem no título dos contos é o recurso ao nome próprio da personagem, que aparece isoladamente, acompanhado de alguma expressão que o modifique ou na forma diminutiva. Em sete desses vinte e seis contos, identificamos a antropomorfização de animais ou coisas em geral ${ }^{31} \mathrm{e}$, em dois deles, referência à personagem no plural $^{32}$. Os procedimentos observados importam para a leitura da obra desse ficcionista brasileiro e não podem e nem devem ser ignorados.

Resta, a partir de agora, isolar caso a caso, seja conto por conto, sejam conjuntos de contos com base em recursos empregados ou em blocos de recursos comuns a eles, e

30 Quase oitenta por cento do total da obra de Rubião.

31 Quase vinte e sete por cento dos vinte e seis contos em que verificamos a presença de personagem-título e mais de vinte e um por cento do total da obra.

32 Quase oito por cento dos vinte e seis contos em que verificamos a presença de personagem-título e mais de seis por cento do total da obra. 
desenvolver a leitura integral dos textos em busca de identificar os procedimentos discursivo-textuais internamente utilizados na composição da personagem-título.

\section{REFERÊNCIAS}

BRUMA (2020). In: DICIO, Dicionário Online de Português. Porto: 7Graus. In https://www.dicio.com.br/bruma/ Acesso em: 22.Set.2020.

CANDIDO, Antonio (1987). "A nova narrativa". In: . Educação pela noite e outros ensaios. São Paulo: Ática, p.199-215.

CARDOSO, Eveline Coelho (2007). "Temas, títulos e epígrafes em Murilo Rubião: reflexões e leituras a partir de "Alfredo" e "Os dragões"”. In: GARCíA, Flavio (Org.). Murilo Rubião e a narrativa do insólito. Rio de Janeiro: Publicações Dialogarts, p.37-45. COMENSAL (2020). In: DICIO, Dicionário Online de Português. Porto: 7Graus. In https://www.dicio.com.br/comensal/. Acesso em: 09.0ut.2020.

GARCíA, Flavio (s/d.). "Insólito ficcional". In: REIS, Carlos; ROAS, David; FURTADO, Filipe; GARCÍA, Flavio; FRANÇA, Júlio (Eds). Dicionário Digital do Insólito Ficcional (e-DDIF). Rio de Janeiro: Dialogarts. In http://www.insolitoficcional.uerj.br/i/ insolito-ficcional/ Acesso em 22.Out.2020.

GOMES, Polyana Pires (2018). As flores do mal dos contos de Murilo Rubião. Raído, Dourados, Vol.12, p.81-93.

INTANGÍVEL (2020). In: DICIO, Dicionário Online de Português. Porto: 7Graus. In https://www.dicio.com.br/intangivel/ Acesso em: 21.Set.2020.

LÓPEZ-PELLISA, Teresa; RUIZ GARZÓN, Ricardo (2019). "Introducción. Las hijas de Metis". In: (Eds.). Insólitas. Narradoras de lo fantástico em Latinoamérica y España. Madrid: Páginas de Espuma, p.XI-XXXI.

REIS, Carlos (2018). Dicionário de Estudos Narrativos. Coimbra: Almedina.

REIS, Carlos (2014). Pessoas de livro: figuração e sobrevida da personagem. Revista de Estudos Literários (Centro de Literatura Portuguesa da Faculdade de Letras da Universidade de Coimbra), v. 4 (Personagens e Figuração), p.43-68.

REIS, Carlos; LOPES, Ana Cristina (1980). Dicionário de Narratologia. Coimbra: Almedina. 
RUBIÃO, Murilo (2010). Murilo Rubião - obra completa. São Paulo: Companhia das Letras.

SILVA, Luciana Morais da (2016). Figurações da personagem e o universo insólito dos novos discursos do fantástico: narrativas curtas de Murilo Rubião, Mário de Carvalho e Mia Couto. Tese (Doutorado em Literatura de Língua Portuguesa; Teoria da Literatura e Literatura Comparada) - Universidade de Coimbra, Coimbra. SILVA, Luciana Morais da (2007). O insólito em "Mariazinha”, de Murilo Rubião. In: GARCÍA, Flavio (Org.). Murilo Rubião e a narrativa do insólito. Rio de Janeiro: Publicações Dialogarts, p.62-72. 